International Journal of Bioscience and Medicine
(ISSN:2575-7814)

\title{
USE OF GLUTAMINE AS AN ADJUVING THERAPY FOR THE NUTRITIONAL AND PHYSIOLOGICAL RESTORATION OF THE BIG BURNED PATIENT
}

\section{Ziane da Conceição das Mercês ${ }^{1 *}$, Gabriela Andersson Antunes Buchmann ${ }^{2}$}

${ }^{1}$ Especialista em Nutrição e exercício voltado ao tratamento e prevenção de doenças, Responsável Técnica na Secretaria de Educação no Município de Aveiro, Pará; ${ }^{2}$ Especialista em Terapia Nutricional em Cuidados Intensivos.

\section{ABSTRACT}

Objective: To analyze the applicability of glutamine in the recovery of the nutritional and physiological status of burn patients. Methods: Study based on a literary review taken from reliable sources such as: The Scientific Electronic Library Online (Scielo), Pubmed, Bireme, Latin American and Caribbean Literature in Health Sciences (Lilacs), Virtual Health Library, the descriptors used were: glutamine ; nutritional therapy; burned; nutrition therapy; burned patients; glutamine, published in the last eleven years (2009-2020).Results: The research was carried out in a literary review format 30 full documents were read, 23 scientific articles were used, 3 bases of the Ministry of Health, 7 were postponed, the arguments used in the composition of the article, were the answer to the problem about applicability about the nutrient with immunomodulatory function glutamine for the recovery of the nutritional and physiological state of burn patients. Conclusion: The research argued about the use of glutamine in the treatment of large burn patients, through data obtained by literary analysis. The results obtained will contribute to the guidelines on the use of immunonutrients to improve the immune response, modulate the inflammatory response, reduce the rates of infectious complications, bringing a possible reduction in hospitalization costs. However, there is a need for further studies focused on this topic, in order to make the benefits of these immunonutrients appreciable for the scientific communi${ }^{*}$ Correspondence to Author: Ziane da Conceição das Mercês Especialista em Nutrição e exercício voltado ao tratamento e prevenção de doenças, Responsável Técnica na Secretaria de Educação no Município de Aveiro, Pará

How to cite this article:

Ziane da Conceição das Mercês, Gabriela Andersson Antunes Buchmann. USE OF GLUTAMINE AS AN ADJUVING THERAPY FOR THE NUTRITIONAL AND PHYSIOLOGICAL RESTORATION OF THE BIG BURNED PATIENT. International Journal of Bioscience and Medicine, 2020; 4:15.

ty, especially in terms of nutritional support more appropriate to supplementation and the recommendation of these nutrients.

Keywords: Immunomodulatory. Big burns. Immunonutrients 